\title{
8 Research Square

Association between ambient air pollution and in vitro fertilization pregnancy outcomes in Taiyuan: A retrospective study in a heavy polluted city in northern China

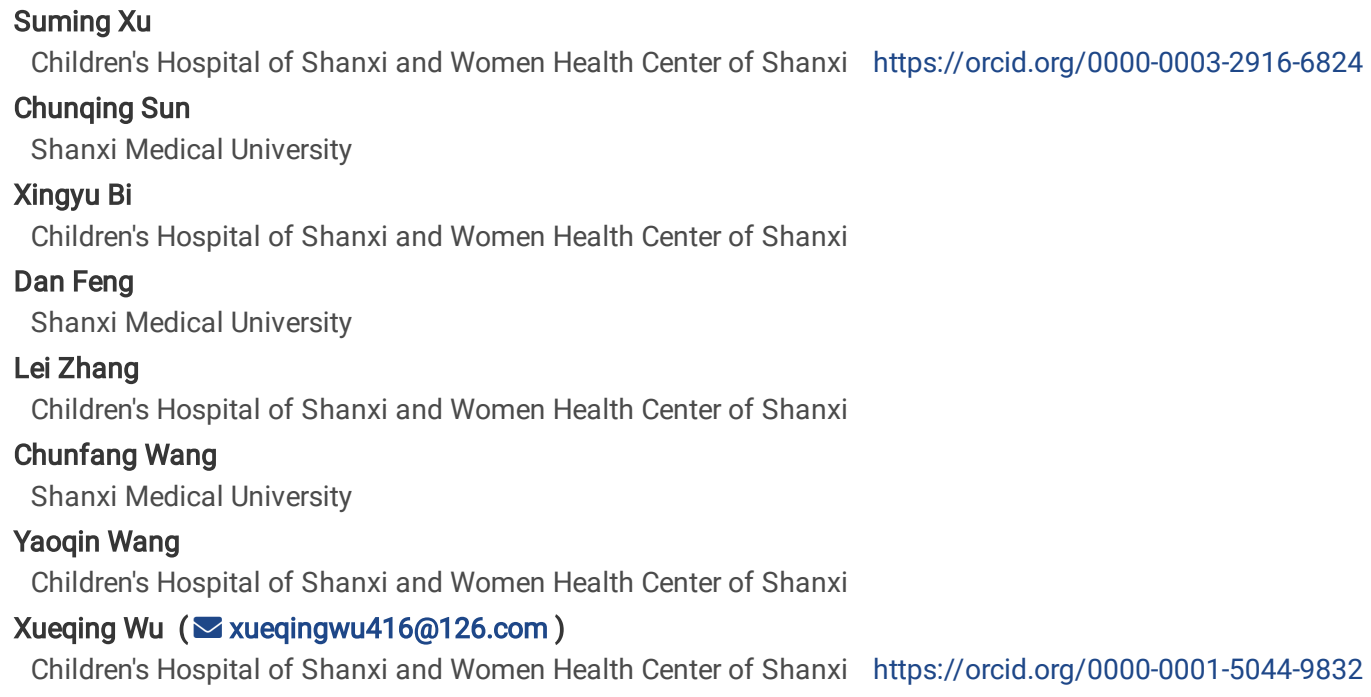

\section{Research}

Keywords: In vitro fertilization, Ambient air pollution, Biochemical pregnancy, Clinical pregnancy

Posted Date: October 19th, 2020

DOI: https://doi.org/10.21203/rs.3.rs-89278/v1

License: @) (1) This work is licensed under a Creative Commons Attribution 4.0 International License. Read Full License 


\section{Abstract}

\section{Background}

Globally, air pollution has a significant impact on human health. However, the effects of air pollution on pregnancy outcomes in patients undergoing in vitro fertilization (IVF) have not been fully understood. In this study, we analyzed the effects of air pollution on IVF pregnancy outcomes in Taiyuan, which is a heavy polluted city in northern China.

\section{Methods}

516 patients who underwent first fresh IVF cycle were enrolled in the retrospective study from January 1, 2015 to May 31, 2020. We collected medical record data from the electronic medical record system and daily average air pollution data from air quality monitoring station. Logistic regression was used to analyze the relationship between six atmospheric pollutants $\left(\mathrm{PM}_{2.5}, \mathrm{PM}_{10}, \mathrm{O}_{3}, \mathrm{NO}_{2}, \mathrm{SO}_{2}, \mathrm{CO}\right)$ and air quality index (AQI) and IVF pregnancy outcomes (biochemical pregnancy and clinical pregnancy) in different exposure periods.

\section{Results}

The results indicated that exposure to $\mathrm{NO}_{2}$ was negatively associated with the odds of biochemical pregnancy and clinical pregnancy, whereas exposure to $\mathrm{O}_{3}$ presented positive association. Furthermore, we also found that AQI was negatively associated with IVF pregnancy outcomes.

\section{Conclusions}

Our findings suggested that exposure to ambient air pollution during any period may have an impact on IVF pregnancy outcomes, and poor air quality is more likely to reduce clinical pregnancy rates.

\section{Introduction}

With the rapid industrialization, urbanization and motorization, air pollution problems are becoming more and more serious, and the effect of air pollution on health has attracted more attention. Air pollutant is a complex mixture of gaseous components, solid and liquid suspended particles in the air [1], mainly includes particulate matter $\leq 10 \mu \mathrm{m}$ in aerodynamic diameter $\left(\mathrm{PM}_{10}\right)$, particulate matter $\leq 2.5 \mu \mathrm{m}$ in aerodynamic diameter $\left(\mathrm{PM}_{2.5}\right)$, sulfur dioxide $\left(\mathrm{SO}_{2}\right)$, carbon monoxide $(\mathrm{CO})$, nitrogen dioxide $\left(\mathrm{NO}_{2}\right)$ and ozone $\left(\mathrm{O}_{3}\right)$. Several studies have shown that air pollution has a variety of negative effects on human health, such as cardiovascular diseases [2, 3], respiratory diseases [4, 5], type 2 diabetes mellitus [6], mental disease [7, 8], and so on. In recent years, more evidences showed that there was a correlation between ambient air pollution and human reproductive outcomes, such as infertility, preeclampsia, miscarriage and preterm delivery $[9,10]$.

Infertility is a global problem. It is reported that about $10 \%$ of the world's population are infertile [11]. Among couples of childbearing age in China, the incidence of infertility has reached $25 \%$, and it is on the rise [12]. With the development of human assisted reproductive technology (ART), it has become an important mean for treatment of infertility. More than 7 million children have been born worldwide since 1978 using ART [13]. Previous studies had reported that both long-term and short-term exposure to air pollutants were associated with decreased probability of the rate of implantation, biochemical pregnancy, clinical pregnancy, and live birth [14-17]. However, the present results are inconsistent. Taiyuan is a typical resource-based city with high pollution, which is rich in coal resources. The relationship between air pollution and pregnancy outcomes in other areas could not directly reflect the status in Taiyuan due to its unique air pollution characteristics. Hence, it was of great significance and urgency to further investigate the effects of ambient air pollutants on IVF pregnancy outcomes in Taiyuan.

Air quality index (AQI) is an index that is used for reporting daily the air quality of the environment where we live [18]. However, no studies reported the effects of AQI on IVF pregnancy outcomes. To further investigate the impact of six ambient air pollution $\left(\mathrm{PM}_{10}, \mathrm{PM}_{2.5}, \mathrm{SO}_{2}, \mathrm{CO}, \mathrm{NO}_{2}\right.$ and $\left.\mathrm{O}_{3}\right)$ and $\mathrm{AQI}$ on IVF pregnancy outcomes, we conducted a retrospective study. The women who received IVF treatment at Center of Reproductive Medicine of Children's Hospital of Shanxi and Women Health Center of Shanxi in Taiyuan were enrolled into the study from 2015 to 2020. Our results would be helpful to further understand the impact of air pollution on pregnancy outcomes of patients underwent IVF in a heavy polluted city in northern China, and provide some theoretical support for the prevention and treatment of infertility patients.

\section{Materials And Methods}

\section{Study design and subjects}

Clinical data from patients who underwent the first fresh IVF cycle were obtained at the Center of Reproductive Medicine of Children's Hospital of Shanxi and Women Health Center of Shanxi between January 1, 2015 and May 31, 2020. In this study, the participants were collected depending on the patients ' residential location. We assumed that they did not relocate during IVF treatment. Additional selection criteria include: 1) patients underwent their first fresh cycle, 2) patients used the conventional controlled ovarian hyperstimulation ( $\mathrm{COH}$ ) protocols, and 3) patients' complete medical record data were accessible. Finally, we included 516 IVF patients for analysis.

\section{IVF procedure}


In general, IVF procedure is divided into four stages: $\mathrm{COH}$, oocyte retrieval, embryo transfer, and pregnancy test. Firstly, $\mathrm{COH}$ protocol was carried out to induce ovulation according to the ovarian response, age and ovarian reserve, in order to promote the development of follicles. Human chorionic gonadotrophin (hCG) was injected when two or more dominant follicles reached $18 \mathrm{~mm}$ or more in diameter. Oocyte retrieval was conducted through transvaginal ultrasound-guided follicle aspiration. Oocytes were fertilized by a conventional IVF or ICSI methods. Embryo transfer was performed 3-5 days after oocyte retrieval. Luteal support was started on the day of oocyte retrieval. Biochemical pregnancy is diagnosed by a serum $\beta$-hCG greater than 30 $\mathrm{mlU} / \mathrm{ml}$ at 2 weeks (14 days) after the embryo transfer. Clinical pregnancy is diagnosed by a gestational sac with fetal heart beat during ultrasound examination after five weeks (35 days) of embryo transfer.

\section{Air pollution data}

The daily air pollution data in Taiyuan were obtained from air quality online analysis platform between January 1, 2015 and May 31, 2020 (http://www.aqistudy.cn/historydata). The air pollution data mainly include the concentration of six air pollutants $\left(\mathrm{PM}_{2.5}\right.$ in $\mu \mathrm{g} / \mathrm{m}^{3}, \mathrm{PM}_{10}$ in $\mu \mathrm{g} / \mathrm{m}^{3}, \mathrm{SO} \mathrm{i}_{2}$ in $\mu \mathrm{g} / \mathrm{m}^{3}, \mathrm{NO}_{2}$ in $\mu \mathrm{g} / \mathrm{m}^{3}, \mathrm{CO}$ in $\mathrm{mg} / \mathrm{m}^{3}, \mathrm{O}_{3}$ in $\mu \mathrm{g} / \mathrm{m}^{3}$ ) and $\mathrm{AQI}$. Based on these data, we calculated average ambient air pollutant concentration during longterm exposure to air pollutants (period 1, period 2 and period 3) and IVF treatment cycle (period 4, period 5, period 6, and period 7). As shown in Fig. 1, these stages are the following: period 1 ( 85 days before the oocyte retrieval to ultrasound to determine pregnancy), period 2 ( 85 days before the oocyte retrieval to serum hCG test), period 3 ( 85 days before the oocyte retrieval to oocyte retrieval), period 4 (gonadotropin (Gn) start to oocyte retrieval; period 5 (oocyte retrieval to embryo transfer), period 6 (embryo transfer to serum hCG test), and period 7 (embryo transfer to ultrasound to determine pregnancy).

\section{Statistical analysis}

Descriptive analyses were presented as count (\%) for categorical variables or as mean \pm standard deviation (SD) for continuous variables, respectively. Air pollutants were summarized by the median and quartiles (25th-50th-75th quartile). Spearman correlation analysis was performed to examine the correlation among the pollutants. Univariate and multivariate logistic regression analyses was used to evaluate the associations between ambient air pollution exposures and IVF pregnancy outcomes. Odd ratios (ORs) and 95\% confidence intervals (Cls) were used to report the result. For multiple logistics analysis, we divided the exposure levels of air pollutants in different expose periods into four groups (Q1: low levels, Q2: medium levels, Q3: high-medium levels, Q4: high levels) according to the quartile, and Q1 group was used as a control, adjusting for age, BMI, duration of infertility, type of infertility, causes of infertility, IVF/ICSI, basal follicle-stimulating hormone (FSH), basal luteinizing hormone (LH), basal estradiol (E2), number of oocytes retrieved for analysis. All statistical analyses were performed using SPSS 22. A p-value of $<0.05$ was considered statistically significant.

\section{Results}

\section{Study population characteristics}

This retrospective population-based cohort study consisted of 516 patients with IVF from January 1, 2015 to May 31, 2020 in Taiyuan. The descriptive statistics of study population was given in Table 1. Among the 516 women, 297 (57.6\%) occurred primary infertility and 219 (42.4\%) occurred secondary infertility. In addition, 382 (74.0\%) underwent IVF and 134 (26.0\%) underwent ICSI. Their mean age, mean BMI and mean duration of infertility were 31.48 years, $22.83 \mathrm{~kg} / \mathrm{m}^{2}$ and 3.5 years, respectively. The main causes of infertility were tubal and uterine factor 270 ( $52.3 \%$ ). Their mean basal hormone levels (FSH, LH and E2) and mean number of oocytes retrieved were $8.77 \mathrm{mlU} / \mathrm{ml}, 4.64 \mathrm{mlU} / \mathrm{ml}, 70.96 \mathrm{pg} / \mathrm{ml}$, and 10.78, respectively. For IVF outcomes, the biochemical pregnancy rate and clinical pregnancy rate were 255 (49.4\%) and 217 (42.1\%), respectively.

\section{Air pollution exposure characteristics}

The average ambient air pollutant concentration for six air pollutants and AQI during different exposure periods were exhibited in Table 2. In addition, we used the Spearman's correlation to examine the correlations among the pollutants. The results showed that concentrations of the air pollutants examined

$\left(\mathrm{PM}_{10}, \mathrm{PM}_{2.5}, \mathrm{SO}_{2}, \mathrm{CO}, \mathrm{NO}_{2}\right)$ were positively correlated (Rang: 0.23 to 0.89$)$, and the correlations had highly significant in statistics ( $\left.\mathrm{P}<0.01\right)$. However, the concentration of $\mathrm{O}_{3}$ was negatively correlated (Rang: -0.13 to -0.80$)$ with significant difference $(P<0.01)$.

\section{Association between air pollution and pregnancy outcomes}

As shown in Table 3, we performed univariate logistic regression analysis of the relationship between 6 air pollutants and AQI and IVF pregnancy outcomes (see Additional file 1 and 2). We found that 6 air pollutants and AQI were not associated with the IVF pregnancy outcomes (P凶0.05). Similarly, we explored the estimated effects by air pollutants quartiles during different expose periods with Q1 as the reference, adjusting for age, BMI, duration of infertility, type of infertility, causes of infertility, IVF/ICSI, basal FSH, basal LH, basal E2, number of oocytes retrieved. It indicated that there was a certain relationship between air pollutants to exposure and IVF pregnancy outcomes.

The result of biochemical pregnancy was shown in Table 3. During period 4, medium levels (Q2) and high levels $(\mathrm{Q} 4)$ of $\mathrm{NO}_{2}$ were significantly associated with reduced odds of biochemical pregnancy. High levels (Q4) of $\mathrm{NO}_{2}$ exposure during period 7 was significantly associated with reduced odds of biochemical pregnancy and decreased in a dose-dependent manner as exposure levels quartiles increasing (P for trend $=0.031)$. On the contrary, medium levels $\mathrm{O}_{3}(\mathrm{Q} 2)$ during period 4 and 5 and high-medium levels $\mathrm{O}_{3}(\mathrm{Q} 3)$ during period 5 were associated with increased odds of biochemical pregnancy.

The results for the clinical pregnancy rate was shown in Table 4. High-medium levels $\mathrm{NO}_{2}(\mathrm{Q} 3)$ during period 1, 3 and 6 and medium levels (Q2) during period 4 were significantly associated with reduced odds of clinical pregnancy. In contrast, high-medium levels $\mathrm{O}_{3}(\mathrm{Q} 3)$ during period 1 and 5 were 
associated with increased odds of clinical pregnancy. For AQI, high-medium levels (Q3) during period 1 and high levels (Q4) during period 4 were significantly associated with reduced odds of clinical pregnancy. The odds of clinical pregnancy showed a decreasing trend $(P$ for trend $=0.005)$ with $A Q I$ quartiles increasing during period 4.

\section{Discussion}

With the deterioration of air quality in recent years, more and more people pay attention to the health effects of air pollution. In this retrospective study, we explored the association between 6 air pollutants and AQI and IVF pregnancy outcomes during long-term exposure (period 1, period 2 and period 3 ) and IVF treatment cycle (period 4, period 5, period 6, and period 7) in Taiyuan. The results suggested that lower pregnancy outcomes in IVF cycles might be linked with worse air environment. The results further supported previous studies that air pollution exposure had the negative influences on IVF pregnancy outcomes.

Previous studies have explored the relationship between air pollution and IVF pregnancy outcomes. A study from three IVF laboratories in the Northeastern United States found that the increase of $\mathrm{NO}_{2}$ concentration was significantly associated with a low chance of pregnancy and live birth [17]. And another study, Boulet et al. reported that exposure to $\mathrm{O}_{3}$ was weakly positively associated with implantation rate and live birth rate, while exposure to $\mathrm{PM} \mathrm{M}_{2.5}$ was not associated with any of IVF treatment outcomes [16]. Perin et al. indicated that high levels of ambient PM during the follicular phase had a higher risk of pregnancy loss in Brazilian women undergoing IVF [19]. Choe et al showed that increase of $\mathrm{PM}_{10}, \mathrm{NO}_{2}$ and $\mathrm{CO}$ were associated with a decreased probability of intrauterine pregnancy in Korea women after adjusting for individual risk factors [20]. Also from South $\mathrm{Korea} \mathrm{Kang}$ et al. showed that exposure to $\mathrm{NO}_{2}$, $\mathrm{PM}_{10}$, and $\mathrm{PM}_{2.5}$ were associated with decreased pregnancy rates in women undergoing fresh IVF-ET treatment from a large, long-term database [15]. Additionally, there have been related reports in China. In Xiamen, Wang et al. retrospectively analyzed the effect of outdoor air pollution on IVF outcomes of frozen-thawed embryo transfer (FET) and fresh embryo transfer in the same period. They found that exposure to high levels of $\mathrm{SO}_{2}$ and $\mathrm{O}_{3}$ were significantly associated with low live birth rates in frozen embryo transfers but had no effect on fresh embryo transfer [21]. In Shenyang, Qiu et al. observed that an inter quartile range (IQR) increasing of $\mathrm{O}_{3}$ during $\mathrm{Gn}$ start to oocyte retrieval and one day before oocyte retrieval was associated with a lower intrauterine pregnancy rate, while there was an inverse association of intrauterine pregnancy with CO two days prior to oocyte retrieval [22]. In Chengdu, Zeng et al. found that expose of $\mathrm{PM}_{2.5}, \mathrm{PM}_{10}, \mathrm{NO}_{2}, \mathrm{SO}_{2}$ and $\mathrm{CO}$ were negatively associated with the odds of biochemical pregnancy and clinical pregnancy except $\mathrm{O}_{3}$, particularly < 35 years younger women [14]. The inconsistency of the above conclusions could be explained as follows: 1) the composition, levels and sources of air pollution vary due to different countries and regions; 2) the individual susceptibility is different due to different genetic backgrounds and lifestyles; 3 ) most of the above studies are retrospective cohort studies, which may increase the possibility of selection bias, failure to control for selection bias potential confounding factors and sample size.

Taiyuan, is a typical heavy industry city characterized by coal-burning pollution, mainly comes from the exhaust emissions of the heavy industries and coalfired heating in winter [5]. With the rapid development of urbanization, motor vehicle exhaust emissions have become one of the main sources of air pollution in Taiyuan city [23]. Additionally, Taiyuan is surrounded on the three sides by mountains that inhibit the dispersion of pollutants. The special basin terrain character and temperature inversion in winter make it difficult to disperse air pollutants. Therefore, the air pollution characteristics of Taiyuan was formed that the dominated pollutant by particulate matter and $\mathrm{SO}_{2}$, accompanied by a large amount of $\mathrm{NO}_{2}$ and $\mathrm{O}_{3}$. Similar to the above results, we also found that air pollutants were associated with reduced biochemical pregnancy rates and clinical pregnancy rates among IVF patients in Taiyuan.

$\mathrm{NO}_{2}$ is a traffic-related air pollutants that was mainly released from vehicle emission and coal combustion [24]. In this study, we found that there was a significant negative correlation between exposure to $\mathrm{NO}_{2}$ and biochemical and clinical pregnancy, while exposure to $\mathrm{O}_{3}$ had the inverse relationship. The results of this study are similar to Zeng's [14]. In addition, Slama et al. reported that high concentrations of $\mathrm{PM}_{2.5}$ and $\mathrm{NO}_{2}$ were associated with lower pregnancy rates in women [25]. In Balb/c mice, Mohallem et al. also found that the failure rate of implantation increased and the live birth rate decreased exposed to high levels of $\mathrm{NO}_{2}$ and $\mathrm{PM}_{2.5}$ [26]. In addition, $\mathrm{O}_{3}$ is a secondary pollutant that is not emitted directly into the atmosphere, but is produced by photochemical reactions between $\mathrm{NO}_{2}$ and hydrocarbons [27]. Therefore, the rise of $\mathrm{O}_{3}$ reflects good air quality to some extent. This not only explains that $\mathrm{O}_{3}$ is positively correlated with pregnancy outcome, but also explains that $\mathrm{O}_{3}$ is negatively correlated with other pollutants and AQI.

$\mathrm{AQI}$ as a quantitative index is to describe air quality status. The higher the AQI value, the more serious the air pollution and it has greater risk to human health [28]. At present, there were no data to analyze the relationship between AQI and IVF pregnancy outcomes. In the study, we found that there was a dose-dependent relationship between AQI and clinical pregnancy rate, and the clinical pregnancy rate decreased with AQI quartiles increase. The results showed that the worse the air quality, the lower the clinical pregnancy rate.

In this study, AQI was firstly used to explore the relationship between air quality and IVF pregnancy outcomes. As a heavy polluted city in northern China, we further explored the effect of air pollutants during different exposure periods on IVF pregnancy outcomes in Taiyuan.

However, certain limitations of this study should be mentioned. First, the level of individual air pollution exposure in this study do not accurately represent individual exposure level. In this study, the data of averaging daily pollutant concentrations was collected from an air pollution monitoring station. In addition, it is difficult to directly measure individual air pollution exposure due to its expensive cost and the patients' compliance. Furthermore, we only conducted the single-pollutant models based on six air pollutants, without the additive and/or interactive effects of two or more pollutants. As an environmental evaluation indicator based on six pollutants, we explore the relationship between AQI and IVF pregnancy outcomes. Third, the number of participants and potential confounders were limited due to retrospective study. Therefore, a prospective study with a large sample size will be more conducive to draw more reliable conclusions. 


\section{Conclusions}

In summary, our findings suggested that air pollution has a certain impact on IVF pregnancy outcomes, especially $\mathrm{NO}_{2}$ and $\mathrm{O}_{3}$. In addition, the results of AQI further indicated that poor air quality was more likely to reduce clinical pregnancy. Thus, to strengthen the protection of IVF infertility patients from air pollutants is beneficial to increase the biochemical pregnancy rate and clinical pregnancy rate.

\section{Abbreviations}

IVF: in vitro fertilization; ART:assisted reproductive technology; $\mathrm{COH}$ :controlled ovarian hyperstimulation; hCG:human chorionic gonadotrophin; $\mathrm{PM}_{10}$ :particulate matter $\leq 10 \mu \mathrm{m}$ in aerodynamic diameter; $\mathrm{PM}_{2.5}$ :particulate matter $\leq 2.5 \mu \mathrm{m}$ in aerodynamic diameter; $\mathrm{SO}_{2}$ :sulfur dioxide; $\mathrm{CO}_{\text {:carbon }}$ monoxide; $\mathrm{NO}_{2}$ :nitrogen dioxide; $\mathrm{O}_{3}$ :ozone; $\mathrm{AQI}$ :air quality index; $\mathrm{BMI}$ :body mass index; $\mathrm{Cl}$ :confidence interval; OR:odds ratio

\section{Declarations}

\section{Acknowledgements}

Not applicable.

\section{Authors' contributions}

All authors read and approved the final manuscript. SX, YW designed the study. SX, CS and LZ analyzed the data. CS and DF collected the data. SX drafted the manuscript. XB, CW and YW revised the manuscript. XW coordinated the study and revised the manuscript.

\section{Funding}

This work was supported by the National Key Research and Development Program (grant number 2018YFC1002103).

\section{Availability of data and materials}

The data used during this study are available from the corresponding author on reasonable request.

\section{Ethics approval and consent to participate}

The study was approved by the Ethics Committee of Children's Hospital of Shanxi and Women Health Center of Shanxi.

\section{Consent for publication}

Not applicable.

\section{Competing interests}

The authors declare that they have no competing interests.

\section{Author details}

${ }^{1}$ Center of Reproductive Medicine, Children's Hospital of Shanxi and Women Health Center of Shanxi, Taiyuan, Shanxi, China. ${ }^{2}$ The Second Hospital of Shanxi Medical University, Shanxi Medical University, Taiyuan, Shanxi, China. ${ }^{3}$ Laboratory Animal Center, Shanxi Medical University, Taiyuan, Shanxi, China.

\section{References}

1. Afsar B, Elsurer Afsar R, Kanbay A, Covic A, Ortiz A, Kanbay M. Air pollution and kidney disease: review of current evidence. Clin Kidney J. 2019;12(1):19-32.

2. Beelen R, Stafoggia M, Raaschou-Nielsen O, Andersen ZJ, Xun WW, Katsouyanni K, et al. Long-term exposure to air pollution and cardiovascular mortality: an analysis of 22 European cohorts. Epidemiology. 2014;25(3):368-78.

3. Xu H, Chen J, Zhao Q, Zhang Y, Wang T, Feng B, et al. Ambient air pollution is associated with cardiac repolarization abnormalities in healthy adults. Environ Res. 2019;171:239-46.

4. Guan W-J, Zheng X-Y, Chung KF, Zhong N-S. Impact of air pollution on the burden of chronic respiratory diseases in China: time for urgent action. Lancet. 2016;388(10054):1939-51.

5. Luo L, Zhang Y, Jiang J, Luan H, Yu C, Nan P, et al. Short-Term Effects of Ambient Air Pollution on Hospitalization for Respiratory Disease in Taiyuan, China: A Time-Series Analysis. Int J Environ Res Public Health. 2018;15(10):2160.

6. Shan A, Zhang Y, Zhang L-W, Chen X, Li X, Wu H, et al. Associations between the incidence and mortality rates of type 2 diabetes mellitus and long-term exposure to ambient air pollution: A 12-year cohort study in northern China. Environ Res. 2020;186:109551. 
7. Altuğ H, Fuks KB, Hüls A, Mayer A-K, Tham R, Krutmann J, et al. Air pollution is associated with depressive symptoms in elderly women with cognitive impairment. Environ Int. 2020;136:105448.

8. Luo Z, Hou Y, Chen G, Wang F, Tu R, Dong X, et al. Long-term effects of ambient air pollutants on suicidal ideation in China: The Henan Rural Cohort Study. Environ Res. 2020;188:109755.

9. Wu J, Ren C, Delfino RJ, Chung J, Wilhelm M, Ritz B. Association between local traffic-generated air pollution and preeclampsia and preterm delivery in the south coast air basin of California. Environ Health Perspect. 2009;117(11):1773-9.

10. Checa Vizcaíno MA, González-Comadran M, Jacquemin B. Outdoor air pollution and human infertility: a systematic review. Fertil Steril. 2016;106(4):897-904.e1.

11. Direkvand-Moghadam A, Sayehmiri K, Delpisheh A, Direkvand-Moghadam A. The global trend of infertility: an original review and meta-analysis. International Journal of Epidemiologic Research. 2014;1(1):35-43.

12. Zhou Z, Zheng D, Wu H, Li R, Xu S, Kang Y, et al. Epidemiology of infertility in China: a population-based study. BJOG. 2018;125(4):432-41.

13. Berntsen S, Söderström-Anttila V, Wennerholm U-B, Laivuori H, Loft A, Oldereid NB, et al. The health of children conceived by ART: 'the chicken or the egg?'. Hum Reprod Update. 2019;25(2):137-58.

14. Zeng X, Jin S, Chen X, Qiu Y. Association between Ambient Air Pollution and Pregnancy Outcomes in Patients Undergoing In Vitro Fertilization in Chengdu, China: A retrospective study. Environ Res. 2020;184:109304.

15. Kang J, Lee JY, Song H, Shin SJ, Kim J. Association between fertilization success rate and ambient air pollution: a possible explanation of within-year variation of fertilization success rate. Obstet Gynecol Sci. 2020;63(1):72-9.

16. Boulet SL, Zhou Y, Shriber J, Kissin DM, Strosnider H, Shin M. Ambient air pollution and in vitro fertilization treatment outcomes. Hum Reprod. 2019;34(10):2036-43.

17. Legro RS, Sauer MV, Mottla GL, Richter KS, Li X, Dodson WC, et al. Effect of air quality on assisted human reproduction. Hum Reprod. 2010;25(5):131724.

18. Demir M, Dindaroğlu T, Yılmaz S. Effects of forest areas on air quality; Aras Basin and its environment. J Environ Health Sci Eng. 2014;12(1):60.

19. Perin PM, Maluf M, Czeresnia CE, Januário DANF, Saldiva PHN. Impact of short-term preconceptional exposure to particulate air pollution on treatment outcome in couples undergoing in vitro fertilization and embryo transfer (IVF/ET). J Assist Reprod Genet. 2010;27(7):371-82.

20. Choe SA, Jun YB, Lee WS, Yoon TK, Kim SY. Association between ambient air pollution and pregnancy rate in women who underwent IVF. Hum Reprod. 2018;33(6):1071-8.

21. Wang X, Cai J, Liu L, Jiang X, Li P, Sha A, et al. Association between outdoor air pollution during in vitro culture and the outcomes of frozen-thawed embryo transfer. Hum Reprod. 2019;34(3):441-51.

22. Qiu J, Dong M, Zhou F, Li P, Kong L, Tan J. Associations between ambient air pollution and pregnancy rate in women who underwent in vitro fertilization in Shenyang, China. Reprod Toxicol. 2019;89:130-5.

23. Han F, Cao J, Peng L, Bai H, Hu D, Mu L, et al. Characteristics of hopanoid hydrocarbons in ambient PM $\mathrm{B}$ and motor vehicle emissions and coal ash in Taiyuan, China. Environ Geochem Health. 2015;37(5):813-29.

24. Tong L, Li K, Zhou Q. Promoted relationship of cardiovascular morbidity with air pollutants in a typical Chinese urban area. PLoS ONE. 2014;9(9):e108076.

25. Slama R, Bottagisi S, Solansky I, Lepeule J, Giorgis-Allemand L, Sram R. Short-term impact of atmospheric pollution on fecundability. Epidemiology. 2013;24(6):871-9.

26. Mohallem SV, de Araújo Lobo DJ, Pesquero CR, Assunção JV, de Andre PA, Saldiva PHN, et al. Decreased fertility in mice exposed to environmental air pollution in the city of Sao Paulo. Environ Res. 2005;98(2):196-202.

27. Quintela-del-Río A, Francisco-Fernández M. Analysis of high level ozone concentrations using nonparametric methods. Sci Total Environ. 2011;409(6):1123-33.

28. China MoEaEotPsRo. Technical Regulation on Ambient Air Quality Index (on trial).http://wwwmeegovcn/ywgz/fgbz/bz/bzwb/jcffbz/201203/t20120302_224166shtml (accessed 21 July 2020). 2012.

\section{Tables}

Table 1 The descriptive statistics of the study population in Taiyuan, China, 2015-2020 $(n=516)$ 


\begin{tabular}{|ll|}
\hline Characteristics & Mean \pm SD/N (\%) \\
\hline Age (years) & $31.48 \pm 4.12$ \\
\hline BMI $\left(\mathrm{kg} / \mathrm{m}^{2}\right)$ & $22.83 \pm 3.17$ \\
\hline Duration of infertility (years) & $3.50 \pm 2.80$ \\
\hline Type of infertility & \\
\hline Primary infertility & $297(57.6)$ \\
\hline Secondary infertility & $219(42.4)$ \\
\hline Causes of infertility & \\
\hline Tubal and Uterine factor & $270(52.3)$ \\
\hline Endometriosis & $24(4.7)$ \\
\hline Ovulatory dysfunction & $12(2.3)$ \\
\hline Male factor & $97(18.8)$ \\
\hline Unexplained & $80(15.5)$ \\
\hline Both factor & $22(4.3)$ \\
\hline Others & $11(2.1)$ \\
\hline IVF/ICSI & $217(42.1)$ \\
\hline IVF & $382(74.0)$ \\
\hline ICSI & $134(26.0)$ \\
\hline Basal hormone levels & \\
\hline Basal FSH (mlU/ml) & \\
\hline Basal LH (mIU/ml) & \\
\hline Basal E2 (pg/ml) & \\
\hline Number of oocytes retrieved & $10.78 \pm 5.26 \pm 2.36$ \\
\hline IVF outcomes & \\
\hline Biochemical pregnancy & 26.88 \\
\hline Clinical pregnancy & \\
\hline
\end{tabular}

Note: Data are presented as mean \pm SD or $\mathrm{n}(\%)$

SD, standard deviation; BMI, body mass index; IVF, in vitro fertilization; ICSI, intracytoplasmic sperm injection; FSH, follicle-stimulating hormone; LH, luteinizing hormone; E2, estradiol

Table 2 The summary statistics of air pollutants and their pairwise correlations in different exposure periods 


\begin{tabular}{|c|c|c|c|c|c|c|c|c|c|c|c|c|c|c|c|}
\hline \multirow{2}{*}{$\begin{array}{l}\text { Exposure } \\
\text { period }\end{array}$} & \multirow{2}{*}{$\begin{array}{l}\text { Air } \\
\text { pollutant }\end{array}$} & \multirow[b]{2}{*}{ Mean } & \multirow[b]{2}{*}{$\mathrm{SD}$} & \multirow[b]{2}{*}{ Min } & \multirow[b]{2}{*}{ Max } & \multicolumn{3}{|c|}{ Percentiles } & \multicolumn{7}{|c|}{ Spearman correlation coefficient } \\
\hline & & & & & & 25th & 50th & 75th & $\mathrm{PM}_{2.5}$ & $\mathrm{PM}_{10}$ & $\mathrm{SO}_{2}$ & $\mathrm{CO}$ & $\mathrm{NO}_{2}$ & $\mathrm{O}_{3}$ & AQI \\
\hline \multirow[t]{7}{*}{ P1 } & $\mathrm{PM}_{2.5}$ & 57.75 & 18.13 & 22.00 & 134.00 & 45.12 & 52.04 & 68.85 & 1.00 & & & & & & \\
\hline & $\mathrm{PM}_{10}$ & 118.52 & 25.06 & 45.62 & 268.00 & 101.67 & 114.51 & 132.29 & 0.89 & 1.00 & & & & & \\
\hline & $\mathrm{SO}_{2}$ & 41.30 & 29.30 & 9.81 & 183.44 & 22.11 & 32.14 & 51.88 & 0.73 & 0.64 & 1.00 & & & & \\
\hline & $\mathrm{CO}$ & 1.39 & 2.82 & 0.77 & 46.22 & 0.93 & 1.16 & 1.38 & 0.72 & 0.57 & 0.91 & 1.00 & & & \\
\hline & $\mathrm{NO}_{2}$ & 46.91 & 9.60 & 14.00 & 91.00 & 39.14 & 45.88 & 53.77 & 0.69 & 0.74 & 0.23 & 0.29 & 1.00 & & \\
\hline & $\mathrm{O}_{3}$ & 93.24 & 35.27 & 32.23 & 227.00 & 63.86 & 91.71 & 118.20 & -0.76 & -0.63 & -0.72 & -0.77 & -0.43 & 1.00 & \\
\hline & AQI & 101.42 & 17.78 & 45.26 & 255.00 & 89.33 & 101.44 & 109.58 & 0.68 & 0.74 & 0.35 & 0.32 & 0.74 & -0.29 & 1.00 \\
\hline \multirow[t]{7}{*}{ P2 } & $\mathrm{PM}_{2.5}$ & 57.69 & 18.62 & 26.22 & 131.97 & 44.16 & 52.31 & 67.77 & 1.00 & & & & & & \\
\hline & $\mathrm{PM}_{10}$ & 118.10 & 25.37 & 60.41 & 202.45 & 102.54 & 115.93 & 131.41 & 0.88 & 1.00 & & & & & \\
\hline & $\mathrm{SO}_{2}$ & 41.66 & 30.76 & 8.78 & 210.25 & 21.17 & 30.67 & 52.02 & 0.77 & 0.62 & 1.00 & & & & \\
\hline & $\mathrm{CO}$ & 1.22 & 0.36 & 0.77 & 2.28 & 0.95 & 1.15 & 1.42 & 0.73 & 0.53 & 0.92 & 1.00 & & & \\
\hline & $\mathrm{NO}_{2}$ & 46.74 & 9.55 & 25.68 & 69.70 & 38.42 & 45.70 & 53.32 & 0.66 & 0.76 & 0.23 & 0.26 & 1.00 & & \\
\hline & $\mathrm{O}_{3}$ & 92.42 & 36.21 & 27.31 & 172.01 & 60.60 & 87.72 & 120.36 & -0.78 & -0.61 & -0.73 & -0.77 & -0.42 & 1.00 & \\
\hline & AQI & 100.65 & 17.12 & 62.14 & 169.60 & 89.36 & 99.75 & 109.21 & 0.70 & 0.75 & 0.40 & 0.38 & 0.73 & -0.31 & 1.00 \\
\hline \multirow[t]{7}{*}{ P3 } & $\mathrm{PM}_{2.5}$ & 57.86 & 20.14 & 24.06 & 174.00 & 43.99 & 51.92 & 68.79 & 1.00 & & & & & & \\
\hline & $\mathrm{PM}_{10}$ & 117.95 & 27.58 & 59.33 & 268.00 & 101.93 & 116.00 & 131.57 & 0.85 & 1.00 & & & & & \\
\hline & $\mathrm{SO}_{2}$ & 43.08 & 36.15 & 8.12 & 354.00 & 20.93 & 30.26 & 54.47 & 0.79 & 0.58 & 1.00 & & & & \\
\hline & $\mathrm{CO}$ & 1.24 & 0.47 & 0.77 & 6.80 & 0.96 & 1.13 & 1.44 & 0.73 & 0.45 & 0.91 & 1.00 & & & \\
\hline & $\mathrm{NO}_{2}$ & 46.72 & 10.18 & 25.53 & 120.00 & 37.41 & 45.95 & 52.90 & 0.66 & 0.76 & 0.26 & 0.27 & 1.00 & & \\
\hline & $\mathrm{O}_{3}$ & 92.05 & 37.29 & 26.02 & 185.00 & 59.12 & 90.77 & 120.39 & -0.76 & -0.56 & -0.72 & -0.74 & -0.42 & 1.00 & \\
\hline & AQI & 100.55 & 19.40 & 60.81 & 230.00 & 88.89 & 98.22 & 109.37 & 0.69 & 0.75 & 0.41 & 0.38 & 0.71 & -0.29 & 1.00 \\
\hline \multirow[t]{7}{*}{ P4 } & $\mathrm{PM}_{2.5}$ & 57.87 & 28.24 & 23.15 & 187.50 & 39.52 & 50.00 & 67.82 & 1.00 & & & & & & \\
\hline & $\mathrm{PM}_{10}$ & 120.80 & 38.17 & 44.92 & 257.44 & 95.96 & 116.53 & 143.72 & 0.86 & 1.00 & & & & & \\
\hline & $\mathrm{SO}_{2}$ & 39.61 & 37.80 & 5.64 & 227.58 & 17.22 & 29.26 & 44.80 & 0.73 & 0.66 & 1.00 & & & & \\
\hline & $\mathrm{CO}$ & 1.17 & 0.43 & 0.65 & 2.95 & 0.86 & 1.06 & 1.39 & 0.74 & 0.55 & 0.86 & 1.00 & & & \\
\hline & $\mathrm{NO}_{2}$ & 47.34 & 11.96 & 22.86 & 81.17 & 38.06 & 46.26 & 54.24 & 0.63 & 0.69 & 0.38 & 0.41 & 1.00 & & \\
\hline & $\mathrm{O}_{3}$ & 94.07 & 45.43 & 0.50 & 221.00 & 60.45 & 92.10 & 123.48 & -0.59 & -0.48 & -0.67 & -0.69 & -0.42 & 1.00 & \\
\hline & AQI & 101.72 & 28.45 & 46.62 & 227.67 & 83.00 & 96.26 & 113.93 & 0.70 & 0.70 & 0.41 & 0.44 & 0.57 & -0.14 & 1.00 \\
\hline \multirow[t]{7}{*}{ P5 } & $\mathrm{PM}_{2.5}$ & 58.72 & 32.73 & 16.00 & 222.75 & 36.31 & 49.75 & 69.38 & 1.00 & & & & & & \\
\hline & $\mathrm{PM}_{10}$ & 120.77 & 46.11 & 35.00 & 331.00 & 86.44 & 112.00 & 150.75 & 0.86 & 1.00 & & & & & \\
\hline & $\mathrm{SO}_{2}$ & 38.21 & 37.42 & 4.25 & 272.50 & 15.75 & 27.00 & 43.13 & 0.63 & 0.64 & 1.00 & & & & \\
\hline & $\mathrm{CO}$ & 1.18 & 0.46 & 0.50 & 3.15 & 0.85 & 1.05 & 1.38 & 0.74 & 0.59 & 0.79 & 1.00 & & & \\
\hline & $\mathrm{NO}_{2}$ & 47.63 & 14.42 & 17.50 & 96.75 & 37.00 & 45.50 & 57.69 & 0.65 & 0.72 & 0.45 & 0.48 & 1.00 & & \\
\hline & $\mathrm{O}_{3}$ & 96.16 & 49.62 & 0.00 & 243.25 & 56.25 & 93.75 & 128.06 & -0.42 & -0.35 & -0.61 & -0.56 & -0.32 & 1.00 & \\
\hline & AQI & 103.33 & 34.96 & 41.75 & 267.00 & 78.25 & 97.63 & 119.25 & 0.72 & 0.72 & 0.35 & 0.48 & 0.57 & -0.16 & 1.00 \\
\hline \multirow[t]{2}{*}{ P6 } & $\mathrm{PM}_{2.5}$ & 59.18 & 30.36 & 24.69 & 214.64 & 40.53 & 48.61 & 68.95 & 1.00 & & & & & & \\
\hline & $\mathrm{PM}_{10}$ & 122.24 & 40.91 & 53.13 & 282.78 & 95.14 & 117.73 & 143.25 & 0.87 & 1.00 & & & & & \\
\hline
\end{tabular}




\begin{tabular}{|c|c|c|c|c|c|c|c|c|c|c|c|c|c|c|c|}
\hline & $\mathrm{SO}_{2}$ & 39.70 & 39.29 & 5.93 & 247.56 & 16.53 & 27.64 & 47.07 & 0.72 & 0.69 & 1.00 & & & & \\
\hline & $\mathrm{CO}$ & 1.19 & 0.47 & 0.62 & 3.23 & 0.87 & 1.05 & 1.36 & 0.74 & 0.58 & 0.85 & 1.00 & & & \\
\hline & $\mathrm{NO}_{2}$ & 47.97 & 13.03 & 26.92 & 89.33 & 38.27 & 45.71 & 55.54 & 0.66 & 0.72 & 0.42 & 0.45 & 1.00 & & \\
\hline & $\mathrm{O}_{3}$ & 95.37 & 47.66 & 9.33 & 213.17 & 51.88 & 94.93 & 128.73 & -0.64 & -0.56 & -0.72 & -0.70 & -0.46 & 1.00 & \\
\hline & AQI & 104.32 & 30.37 & 51.13 & 258.36 & 84.20 & 98.94 & 115.53 & 0.64 & 0.64 & 0.34 & 0.43 & 0.53 & -0.13 & 1.00 \\
\hline \multirow[t]{7}{*}{ P7 } & $\mathrm{PM}_{2.5}$ & 58.64 & 26.36 & 27.44 & 199.33 & 41.54 & 49.64 & 67.13 & 1.00 & & & & & & \\
\hline & $\mathrm{PM}_{10}$ & 120.68 & 36.15 & 57.39 & 264.92 & 97.59 & 118.90 & 134.86 & 0.88 & 1.00 & & & & & \\
\hline & $\mathrm{SO}_{2}$ & 40.16 & 38.42 & 6.25 & 228.25 & 17.59 & 26.04 & 47.83 & 0.81 & 0.70 & 1.00 & & & & \\
\hline & $\mathrm{CO}$ & 1.20 & 0.45 & 0.67 & 3.03 & 0.86 & 1.05 & 1.42 & 0.80 & 0.58 & 0.88 & 1.00 & & & \\
\hline & $\mathrm{NO}_{2}$ & 47.68 & 11.84 & 30.08 & 83.42 & 37.90 & 45.74 & 56.59 & 0.70 & 0.76 & 0.43 & 0.46 & 1.00 & & \\
\hline & $\mathrm{O}_{3}$ & 95.97 & 47.57 & 22.06 & 198.36 & 50.40 & 96.67 & 135.72 & -0.80 & -0.69 & -0.78 & -0.76 & -0.54 & 1.00 & \\
\hline & AQI & 104.12 & 25.30 & 62.81 & 241.58 & 89.26 & 98.22 & 115.93 & 0.55 & 0.56 & 0.35 & 0.39 & 0.56 & -0.22 & 1.00 \\
\hline
\end{tabular}

$\mathrm{P} 1$, period 1; P2, period 2; P3, period 3; P4, period 4; P5, period 5; P6, period 6; P7, period 7; $\mathrm{PM}_{10}$, particulate matter $\leq 10 \mu \mathrm{m}$ in aerodynamic diameter; $\mathrm{PM}_{2.5}$, particulate matter $\leq 2.5 \mu \mathrm{m}$ in aerodynamic diameter; $\mathrm{SO}_{2}$, sulfur dioxide; $\mathrm{CO}$, carbon monoxide; $\mathrm{NO}_{2}$, nitrogen dioxide; $\mathrm{O}_{3}$, ozone; $\mathrm{AQI}$, air quality index; SD: standard deviation

Table 3 Risk analysis between air pollutants quartiles and biochemical pregnancy outcome during each exposure period 


\begin{tabular}{|c|c|c|c|c|c|c|c|c|}
\hline \multirow{2}{*}{$\begin{array}{l}\text { Air } \\
\text { pollutant }\end{array}$} & \multirow{2}{*}{$\begin{array}{l}\text { Exposure } \\
\text { period }\end{array}$} & $\mathrm{P} 1$ & $\mathrm{P} 2$ & P3 & P4 & P5 & P6 & P7 \\
\hline & & AOR $(95 \% \mathrm{Cl})$ & AOR (95\% Cl) & AOR $(95 \% \mathrm{Cl})$ & AOR $(95 \% \mathrm{Cl})$ & AOR $(95 \% \mathrm{Cl})$ & $\operatorname{AOR}(95 \% \mathrm{Cl})$ & $\operatorname{AOR}(95 \% \mathrm{Cl})$ \\
\hline \multicolumn{9}{|l|}{$\mathrm{PM}_{2.5}$} \\
\hline \multicolumn{9}{|l|}{$\left(\mu \mathrm{g} / \mathrm{m}^{3}\right)$} \\
\hline & Q1 & $\begin{array}{l}1.00 \\
\text { \reference } \rrbracket\end{array}$ & $\begin{array}{l}1.00 \\
\text { 『reference } \rrbracket\end{array}$ & 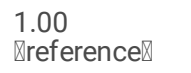 & $\begin{array}{l}1.00 \\
\text { \reference } \rrbracket\end{array}$ & $\begin{array}{l}1.00 \\
\text { \reference } \rrbracket\end{array}$ & $\begin{array}{l}1.00 \\
\text { 『reference } \\
end{array}$ & $\begin{array}{l}1.00 \\
\text { 『reference】 }\end{array}$ \\
\hline & Q2 & $\begin{array}{l}0.886(0.359 \\
2.187)\end{array}$ & $\begin{array}{l}0.948(0.382 \\
2.354)\end{array}$ & $\begin{array}{l}0.575(0.229 \\
1.441)\end{array}$ & $\begin{array}{l}1.731(0.666 \\
4.502)\end{array}$ & $\begin{array}{l}0.983(0.386 \\
2.502)\end{array}$ & $\begin{array}{l}1.353(0.555 \\
3.295)\end{array}$ & $\begin{array}{l}0.978(0.403 \\
2.375)\end{array}$ \\
\hline & Q3 & $\begin{array}{l}0.805(0.316 \\
2.050)\end{array}$ & $\begin{array}{l}1.183(0.435 \\
3.215)\end{array}$ & $\begin{array}{l}0.836(0.305 \\
2.295)\end{array}$ & $\begin{array}{l}1.894(0.738 \\
4.865)\end{array}$ & $\begin{array}{l}0.642(0.254 \\
1.624)\end{array}$ & $\begin{array}{l}1.675(0.631 \\
4.447)\end{array}$ & $\begin{array}{l}1.290(0.513 \\
3.243)\end{array}$ \\
\hline & Q4 & $\begin{array}{l}0.653(0.243 \\
1.754)\end{array}$ & $\begin{array}{l}0.742(0.264 \\
2.087)\end{array}$ & $\begin{array}{l}0.715(0.264 \\
1.942)\end{array}$ & $\begin{array}{l}0.621(0.228 \\
1.696)\end{array}$ & $\begin{array}{l}0.537(0.200 \\
1.438)\end{array}$ & $\begin{array}{l}0.696(0.271 \\
1.789)\end{array}$ & $\begin{array}{l}0.490(0.182 \\
1.316)\end{array}$ \\
\hline & $P$ for trend & 0.386 & 0.695 & 0.798 & 0.401 & 0.125 & 0.504 & 0.279 \\
\hline \multicolumn{9}{|l|}{$\mathrm{PM}_{10}$} \\
\hline \multicolumn{9}{|l|}{$\left(\mu \mathrm{g} / \mathrm{m}^{3}\right)$} \\
\hline & Q1 & $\begin{array}{l}1.00 \\
\text { 『reference } ~\end{array}$ & $\begin{array}{l}1.00 \\
\text { 『reference } \\
end{array}$ & $\begin{array}{l}1.00 \\
\text { 『reference }\end{array}$ & $\begin{array}{l}1.00 \\
\text { 『reference } \rrbracket\end{array}$ & $\begin{array}{l}1.00 \\
\text { 『reference区 }\end{array}$ & $\begin{array}{l}1.00 \\
\text { 『reference } \\
end{array}$ & $\begin{array}{l}1.00 \\
\text { 『reference『 }\end{array}$ \\
\hline & Q2 & $\begin{array}{l}0.938(0.389 \\
2.262)\end{array}$ & $\begin{array}{l}0.881(0.361 \\
2.149)\end{array}$ & $\begin{array}{l}1.280(0.533 \\
3.072)\end{array}$ & $\begin{array}{l}1.958(0.793 \\
4.829)\end{array}$ & $\begin{array}{l}1.224(0.502 \\
2.987)\end{array}$ & $\begin{array}{l}0.690(0.280 \\
1.700)\end{array}$ & $\begin{array}{l}0.758(0.307 \\
1.867)\end{array}$ \\
\hline & Q3 & $\begin{array}{l}0.728(0.280 \\
1.893)\end{array}$ & $\begin{array}{l}1.096(0.413 \\
2.909)\end{array}$ & $\begin{array}{l}1.454(0.558 \\
3.785)\end{array}$ & $\begin{array}{l}1.632(0.620 \\
4.297)\end{array}$ & $\begin{array}{l}0.751(0.311 \\
1.810)\end{array}$ & $\begin{array}{l}1.745(0.705 \\
4.316)\end{array}$ & $\begin{array}{l}1.324(0.550 \\
3.187)\end{array}$ \\
\hline & Q4 & $\begin{array}{l}0.687(0.261 \\
1.808)\end{array}$ & $\begin{array}{l}0.596(0.219 \\
1.617)\end{array}$ & $\begin{array}{l}0.782(0.294 \\
2.075)\end{array}$ & $\begin{array}{l}0.528(0.203 \\
1.374)\end{array}$ & $\begin{array}{l}0.825(0.324 \\
2.099)\end{array}$ & $\begin{array}{l}0.701(0.274 \\
1.790)\end{array}$ & $\begin{array}{l}0.581 \\
1.526)\end{array}(0.221$ \\
\hline & $P$ for trend & 0.362 & 0.422 & 0.728 & 0.159 & 0.446 & 0.986 & 0.566 \\
\hline \multicolumn{9}{|l|}{$\mathrm{SO}_{2}$} \\
\hline \multicolumn{9}{|l|}{$\left(\mu \mathrm{g} / \mathrm{m}^{3}\right)$} \\
\hline & Q1 & $\begin{array}{l}1.00 \\
\text { 『reference } \rrbracket\end{array}$ & $\begin{array}{l}1.00 \\
\text { 『reference } \bigotimes\end{array}$ & 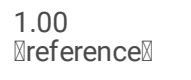 & 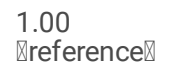 & $\begin{array}{l}1.00 \\
\text { 『reference } \rrbracket\end{array}$ & 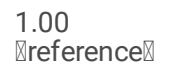 & $\begin{array}{l}1.00 \\
\text { 『reference } \rrbracket\end{array}$ \\
\hline & Q2 & $\begin{array}{l}0.589(0.229 \\
1.513)\end{array}$ & $\begin{array}{l}1.014(0.394 \\
2.613)\end{array}$ & $\begin{array}{l}0.906(0.338 \\
2.430)\end{array}$ & $\begin{array}{l}0.628(0.236 \\
1.666)\end{array}$ & $\begin{array}{l}0.777(0.293 \\
2.062)\end{array}$ & $\begin{array}{l}0.968(0.366 \\
2.557)\end{array}$ & $\begin{array}{l}1.199(0.455 \\
3.163)\end{array}$ \\
\hline & Q3 & $\begin{array}{l}0.730(0.245 \\
2.175)\end{array}$ & $\begin{array}{l}0.857(0.296 \\
2.479)\end{array}$ & $\begin{array}{l}1.422(0.495 \\
4.086)\end{array}$ & $\begin{array}{l}1.259(0.489 \\
3.238)\end{array}$ & $\begin{array}{l}0.843(0.324 \\
2.194)\end{array}$ & $\begin{array}{l}1.117(0.451 \\
2.765)\end{array}$ & $\begin{array}{l}0.954(0.367 \\
2.480)\end{array}$ \\
\hline & Q4 & $\begin{array}{l}0.805(0.302 \\
2.140)\end{array}$ & $\begin{array}{l}1.149(0.432 \\
3.055)\end{array}$ & $\begin{array}{l}1.107(0.406 \\
3.020)\end{array}$ & $\begin{array}{l}0.876(0.342 \\
2.244)\end{array}$ & $\begin{array}{l}1.005(0.373 \\
2.707)\end{array}$ & $\begin{array}{l}1.007(0.391 \\
2.593)\end{array}$ & $\begin{array}{l}0.712(0.258 \\
1.967)\end{array}$ \\
\hline & $P$ for trend & 0.937 & 0.8 & 0.655 & 0.907 & 0.892 & 0.915 & 0.39 \\
\hline \multicolumn{9}{|l|}{$\begin{array}{l}\mathrm{CO} \\
\left(\mathrm{mg} / \mathrm{m}^{3}\right)\end{array}$} \\
\hline & Q1 & $\begin{array}{l}1.00 \\
\text { 『reference } ~\end{array}$ & 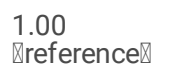 & 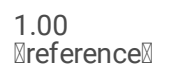 & $\begin{array}{l}1.00 \\
\text { 『reference } \rrbracket\end{array}$ & $\begin{array}{l}1.00 \\
\text { 『reference } ~\end{array}$ & $\begin{array}{l}1.00 \\
\text { 『reference区 }\end{array}$ & $\begin{array}{l}1.00 \\
\text { \reference } ~\end{array}$ \\
\hline & Q2 & $\begin{array}{l}0.554(0.209 \\
1.472)\end{array}$ & $\begin{array}{l}0.710(0.254 \\
1.984)\end{array}$ & $\begin{array}{l}0.729(0.266 \\
1.999)\end{array}$ & $\begin{array}{l}0.582(0.206 \\
1.646)\end{array}$ & $\begin{array}{l}0.936(0.351 \\
2.496)\end{array}$ & $\begin{array}{l}0.682(0.259 \\
1.800)\end{array}$ & $\begin{array}{l}0.733(0.278 \\
1.936)\end{array}$ \\
\hline & Q3 & $\begin{array}{l}0.677(0.239 \\
1.913)\end{array}$ & $\begin{array}{l}0.725(0.258 \\
2.038)\end{array}$ & $\begin{array}{l}0.694(0.250 \\
1.923)\end{array}$ & $\begin{array}{l}0.879(0.317 \\
2.437)\end{array}$ & $\begin{array}{l}0.472(0.171 \\
1.307)\end{array}$ & $\begin{array}{l}0.582 \\
1.528)\end{array}(0.222$ & $\begin{array}{l}1.101(0.402 \\
3.011)\end{array}$ \\
\hline & Q4 & $\begin{array}{l}0.791(0.292 \\
2.139)\end{array}$ & $\begin{array}{l}0.873(0.312 \\
2.444)\end{array}$ & $\begin{array}{l}1.007(0.358 \\
2.828)\end{array}$ & $\begin{array}{l}0.491(0.168 \\
1.438)\end{array}$ & $\begin{array}{l}0.540 \\
1.564)\end{array}$ & $\begin{array}{l}0.550 \\
1.509)\end{array}$ & $\begin{array}{l}0.552 \\
1.589)\end{array}(0.192$ \\
\hline & $P$ for trend & 0.944 & 0.957 & 0.863 & 0.361 & 0.097 & 0.245 & 0.462 \\
\hline \multirow{2}{*}{\multicolumn{9}{|c|}{$\begin{array}{l}\mathrm{NO}_{2} \\
\left(\mu \mathrm{g} / \mathrm{m}^{3}\right)\end{array}$}} \\
\hline & & & & & & & & \\
\hline & Q1 & $\begin{array}{l}1.00 \\
\text { 『reference } \rrbracket\end{array}$ & $\begin{array}{l}1.00 \\
\text { 『reference } \mathbb{}\end{array}$ & $\begin{array}{l}1.00 \\
\text { 『reference区 }\end{array}$ & $\begin{array}{l}1.00 \\
\text { đreference区 }\end{array}$ & $\begin{array}{l}1.00 \\
\text { \reference区 }\end{array}$ & 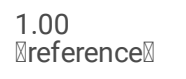 & $\begin{array}{l}1.00 \\
\text { đreference } \rrbracket\end{array}$ \\
\hline & Q2 & $\begin{array}{l}0.734(0.309 \\
1.740)\end{array}$ & $\begin{array}{l}0.959(0.402 \\
2.287)\end{array}$ & $\begin{array}{l}1.069(0.431 \\
2.647)\end{array}$ & $\begin{array}{l}0.333(0.132 \\
0.838)\end{array}$ & $\begin{array}{l}0.486(0.205 \\
1.154)\end{array}$ & $\begin{array}{l}1.027(0.394 \\
2.678)\end{array}$ & $\begin{array}{l}0.521(0.218 \\
1.249)\end{array}$ \\
\hline
\end{tabular}




\begin{tabular}{|c|c|c|c|c|c|c|c|}
\hline Q3 & $\begin{array}{l}0.501(0.206 \\
1.216)\end{array}$ & $\begin{array}{l}0.670(0.273 \\
1.644)\end{array}$ & $\begin{array}{l}0.671(0.284 \\
1.584)\end{array}$ & $\begin{array}{l}1.189(0.494 \\
2.862)\end{array}$ & $\begin{array}{l}0.668(0.286 \\
1.560)\end{array}$ & $\begin{array}{l}0.677(0.302 \\
1.517)\end{array}$ & $\begin{array}{l}0.445(0.181 \\
1.098)\end{array}$ \\
\hline Q4 & $\begin{array}{l}0.440(0.170 \\
1.135)\end{array}$ & $\begin{array}{l}0.480(0.191 \\
1.209)\end{array}$ & $\begin{array}{l}0.646(0.261 \\
1.597)\end{array}$ & $\begin{array}{l}0.352(0.133 \\
0.932)\end{array}$ & $\begin{array}{l}0.662 \text { (0.249 } \\
1.757)\end{array}$ & $\begin{array}{l}0.682(0.267 \\
1.741)\end{array}$ & $\begin{array}{l}0.374(0.141 \\
0.990)\end{array}$ \\
\hline$P$ for trend & 0.054 & 0.095 & 0.24 & 0.283 & 0.417 & 0.287 & 0.031 \\
\hline \multicolumn{8}{|l|}{$\begin{array}{l}\mathrm{O}_{3} \\
\left(\mu \mathrm{g} / \mathrm{m}^{3}\right)\end{array}$} \\
\hline Q1 & $\begin{array}{l}1.00 \\
\text { 『reference『 }\end{array}$ & $\begin{array}{l}1.00 \\
\text { 『reference区 }\end{array}$ & $\begin{array}{l}1.00 \\
\text { 『reference区 }\end{array}$ & $\begin{array}{l}1.00 \\
\text { 『reference区 }\end{array}$ & $\begin{array}{l}1.00 \\
\text { 『reference区 }\end{array}$ & $\begin{array}{l}1.00 \\
\text { 『reference区 }\end{array}$ & $\begin{array}{l}1.00 \\
\text { 『reference区 }\end{array}$ \\
\hline Q2 & $\begin{array}{l}2.313(0.910 \\
5.881)\end{array}$ & $\begin{array}{l}1.336(0.538 \\
3.319)\end{array}$ & $\begin{array}{l}1.169(0.481 \\
2.844)\end{array}$ & $\begin{array}{l}2.608(1.046 \\
6.504)\end{array}$ & $\begin{array}{l}3.261(1.237 \\
8.595)\end{array}$ & $\begin{array}{l}1.965(0.776 \\
4.975)\end{array}$ & $\begin{array}{l}2.409(0.913 \\
6.359)\end{array}$ \\
\hline Q3 & $\begin{array}{l}2.040(0.817 \\
5.096)\end{array}$ & $\begin{array}{l}1.148(0.457 \\
2.886)\end{array}$ & $\begin{array}{l}1.143(0.458 \\
2.853)\end{array}$ & $\begin{array}{l}1.875(0.743 \\
4.735)\end{array}$ & $\begin{array}{l}2.739(1.026 \\
7.310)\end{array}$ & $\begin{array}{l}2.236(0.846 \\
5.911)\end{array}$ & $\begin{array}{l}1.998(0.734 \\
5.437)\end{array}$ \\
\hline Q4 & $\begin{array}{l}1.472(0.566 \\
3.832)\end{array}$ & $\begin{array}{l}1.391(0.562 \\
3.442)\end{array}$ & $\begin{array}{l}1.143(0.473 \\
2.763)\end{array}$ & $\begin{array}{l}1.743(0.688 \\
4.421)\end{array}$ & $\begin{array}{l}2.175(0.787 \\
6.010)\end{array}$ & $\begin{array}{l}1.998(0.737 \\
5.418)\end{array}$ & $\begin{array}{l}2.008(0.695 \\
5.802)\end{array}$ \\
\hline$P$ for trend & 0.472 & 0.56 & 0.783 & 0.385 & 0.234 & 0.19 & 0.35 \\
\hline \multicolumn{8}{|l|}{ AQI } \\
\hline Q1 & $\begin{array}{l}1.00 \\
\text { 『reference区 }\end{array}$ & $\begin{array}{l}1.00 \\
\text { 『reference】 }\end{array}$ & $\begin{array}{l}1.00 \\
\text { 『reference区 }\end{array}$ & $\begin{array}{l}1.00 \\
\text { 『reference区 }\end{array}$ & $\begin{array}{l}1.00 \\
\text { 『reference区 }\end{array}$ & $\begin{array}{l}1.00 \\
\text { 『reference区 }\end{array}$ & $\begin{array}{l}1.00 \\
\text { \reference } \rrbracket\end{array}$ \\
\hline Q2 & $\begin{array}{l}1.362(0.552 \\
3.364)\end{array}$ & $\begin{array}{l}1.007(0.413 \\
2.454)\end{array}$ & $\begin{array}{l}1.698(0.679 \\
4.250)\end{array}$ & $\begin{array}{l}1.774(0.691 \\
4.554)\end{array}$ & $\begin{array}{l}0.950(0.406 \\
2.219)\end{array}$ & $\begin{array}{l}1.379(0.587 \\
3.242)\end{array}$ & $\begin{array}{l}1.696(0.714 \\
4.030)\end{array}$ \\
\hline Q3 & $\begin{array}{l}0.684(0.280 \\
1.675)\end{array}$ & $\begin{array}{l}1.320(0.538 \\
3.237)\end{array}$ & $\begin{array}{l}1.556(0.625 \\
3.871)\end{array}$ & $\begin{array}{l}0.941(0.366 \\
2.421)\end{array}$ & $\begin{array}{l}1.020(0.408 \\
2.554)\end{array}$ & $\begin{array}{l}0.846(0.339 \\
2.112)\end{array}$ & $\begin{array}{l}0.844(0.343 \\
2.079)\end{array}$ \\
\hline Q4 & $\begin{array}{l}0.881(0.354 \\
2.193)\end{array}$ & $\begin{array}{l}0.667(0.269 \\
1.656)\end{array}$ & $\begin{array}{l}0.855(0.344 \\
2.123)\end{array}$ & $\begin{array}{l}0.476(0.190 \\
1.192)\end{array}$ & $\begin{array}{l}0.640(0.250 \\
1.636)\end{array}$ & $\begin{array}{l}0.878(0.341 \\
2.260)\end{array}$ & $\begin{array}{l}0.808(0.320 \\
2.040)\end{array}$ \\
\hline $\mathrm{P}$ for trend & 0.481 & 0.561 & 0.742 & 0.059 & 0.419 & 0.589 & 0.403 \\
\hline
\end{tabular}

AOR, adjusted odds ratio; Cl: confidence interval; P1, period 1; P2, period 2; P3, period 3; P4, period 4; P5, period 5; P6, period 6; P7, period 7; PM 10 , particulate

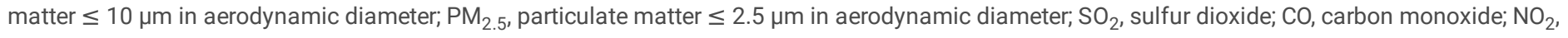
nitrogen dioxide; $\mathrm{O}_{3}$, ozone; $\mathrm{AQI}$, air quality index; $\mathrm{Q} 1$, the first quartile; $\mathrm{Q} 2$, the second quartile; $\mathrm{Q}$, the third quartile; $\mathrm{Q} 4$, the fourth quartile.

Adjusting for age, BMI, duration of infertility, type of infertility, causes of infertility, IVF/ICSI, basal FSH, basal LH, basal E2 and number of oocytes retrieved.

Table 4 Risk analysis between air pollutants quartiles and clinical pregnancy outcome during each exposure period 


\begin{tabular}{|c|c|c|c|c|c|c|c|c|}
\hline \multirow{2}{*}{$\begin{array}{l}\text { Air } \\
\text { pollutant }\end{array}$} & \multirow{2}{*}{$\begin{array}{l}\text { Exposure } \\
\text { period }\end{array}$} & P1 & P2 & P3 & P4 & P5 & P6 & P7 \\
\hline & & AOR $(95 \% \mathrm{Cl})$ & AOR $(95 \% \mathrm{Cl})$ & AOR $(95 \% \mathrm{Cl})$ & AOR $(95 \% \mathrm{Cl})$ & AOR $(95 \% \mathrm{Cl})$ & AOR $(95 \% \mathrm{Cl})$ & AOR $(95 \% \mathrm{Cl})$ \\
\hline \multicolumn{9}{|l|}{$\mathrm{PM}_{2.5}$} \\
\hline \multicolumn{9}{|l|}{$\left(\mu \mathrm{g} / \mathrm{m}^{3}\right)$} \\
\hline & Q1 & $\begin{array}{l}1.00 \\
\text { 『reference } \\
end{array}$ & $\begin{array}{l}1.00 \\
\text { 『reference } \\
end{array}$ & $\begin{array}{l}1.00 \\
\text { đreference区 }\end{array}$ & $\begin{array}{l}1.00 \\
\text { 『reference『 }\end{array}$ & $\begin{array}{l}1.00 \\
\text { 『reference区 }\end{array}$ & $\begin{array}{l}1.00 \\
\text { 『reference区 }\end{array}$ & $\begin{array}{l}1.00 \\
\text { đreference『 }\end{array}$ \\
\hline & Q2 & $\begin{array}{l}1.342(0.545 \\
3.307)\end{array}$ & $\begin{array}{l}1.136(0.450 \\
2.867)\end{array}$ & $\begin{array}{l}0.431(0.166 \\
1.115)\end{array}$ & $\begin{array}{l}1.815(0.688 \\
4.787)\end{array}$ & $\begin{array}{l}0.600(0.237 \\
1.521)\end{array}$ & $\begin{array}{l}1.432(0.579 \\
3.540)\end{array}$ & $\begin{array}{l}1.825(0.734 \\
4.535)\end{array}$ \\
\hline & Q3 & $\begin{array}{l}0.850(0.329 \\
2.199)\end{array}$ & $\begin{array}{l}1.027(0.370 \\
2.850)\end{array}$ & $\begin{array}{l}0.622(0.223 \\
1.735)\end{array}$ & $\begin{array}{l}2.149(0.826 \\
5.592)\end{array}$ & $\begin{array}{l}0.517(0.204 \\
1.312)\end{array}$ & $\begin{array}{l}1.519(0.568 \\
4.064)\end{array}$ & $\begin{array}{l}2.019(0.791 \\
5.155)\end{array}$ \\
\hline & Q4 & $\begin{array}{l}0.842(0.313 \\
2.265)\end{array}$ & $\begin{array}{l}0.843(0.298 \\
2.384)\end{array}$ & $\begin{array}{l}0.529(0.192 \\
1.459)\end{array}$ & $\begin{array}{l}0.674(0.238 \\
1.910)\end{array}$ & $\begin{array}{l}0.646(0.245 \\
1.702)\end{array}$ & $\begin{array}{l}0.967(0.371 \\
2.523)\end{array}$ & $\begin{array}{l}1.037(0.387 \\
2.783)\end{array}$ \\
\hline & $P$ for trend & 0.503 & 0.658 & 0.465 & 0.55 & 0.356 & 0.898 & 0.852 \\
\hline \multirow{2}{*}{\multicolumn{9}{|c|}{$\begin{array}{l}\mathrm{PM}_{10} \\
\left(\mu \mathrm{g} / \mathrm{m}^{3}\right)\end{array}$}} \\
\hline & & & & & & & & \\
\hline & Q1 & $\begin{array}{l}1.00 \\
\text { 『reference区 }\end{array}$ & $\begin{array}{l}1.00 \\
\text { 『reference区 }\end{array}$ & $\begin{array}{l}1.00 \\
\text { 『reference区 }\end{array}$ & $\begin{array}{l}1.00 \\
\text { 『reference区 }\end{array}$ & $\begin{array}{l}1.00 \\
\text { 『reference区 }\end{array}$ & $\begin{array}{l}1.00 \\
\text { 『reference区 }\end{array}$ & $\begin{array}{l}1.00 \\
\text { đreference区 }\end{array}$ \\
\hline & Q2 & $\begin{array}{l}0.956(0.396 \\
2.310)\end{array}$ & $\begin{array}{l}0.554(0.223 \\
1.376)\end{array}$ & $\begin{array}{l}0.795(0.326 \\
1.939)\end{array}$ & $\begin{array}{l}1.962(0.788 \\
4.882)\end{array}$ & $\begin{array}{l}1.122(0.456 \\
2.763)\end{array}$ & $\begin{array}{l}0.948(0.375 \\
2.399)\end{array}$ & $\begin{array}{l}1.237(0.492 \\
3.106)\end{array}$ \\
\hline & Q3 & $\begin{array}{l}0.641(0.241 \\
1.703)\end{array}$ & $\begin{array}{l}0.737(0.277 \\
1.960)\end{array}$ & $\begin{array}{l}0.810(0.312 \\
2.102)\end{array}$ & $\begin{array}{l}1.533(0.589 \\
3.993)\end{array}$ & $\begin{array}{l}1.196(0.493 \\
2.899)\end{array}$ & $\begin{array}{l}2.291(0.920 \\
5.705)\end{array}$ & $\begin{array}{l}2.031(0.842 \\
4.901)\end{array}$ \\
\hline & Q4 & $\begin{array}{l}0.782(0.298 \\
2.055)\end{array}$ & $\begin{array}{l}0.483(0.175 \\
1.330)\end{array}$ & $\begin{array}{l}0.567(0.212 \\
1.517)\end{array}$ & $\begin{array}{l}0.487(0.178 \\
1.332)\end{array}$ & $\begin{array}{l}1.035(0.399 \\
2.685)\end{array}$ & $\begin{array}{l}1.009(0.388 \\
2.628)\end{array}$ & $\begin{array}{l}0.920(0.342 \\
2.475)\end{array}$ \\
\hline & $P$ for trend & 0.446 & 0.274 & 0.294 & 0.144 & 0.892 & 0.475 & 0.703 \\
\hline \multicolumn{9}{|l|}{$\begin{array}{l}\mathrm{SO}_{2} \\
\left(\mu \mathrm{g} / \mathrm{m}^{3}\right)\end{array}$} \\
\hline & Q1 & $\begin{array}{l}1.00 \\
\text { \#reference区 }\end{array}$ & 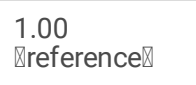 & $\begin{array}{l}1.00 \\
\text { \#reference区 }\end{array}$ & $\begin{array}{l}1.00 \\
\text { đreference区 }\end{array}$ & $\begin{array}{l}1.00 \\
\text { \#reference区 }\end{array}$ & 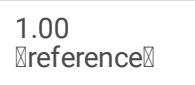 & $\begin{array}{l}1.00 \\
\text { đreference区 }\end{array}$ \\
\hline & Q2 & $\begin{array}{l}1.096(0.423 \\
2.841)\end{array}$ & $\begin{array}{l}1.796(0.670 \\
4.814)\end{array}$ & $\begin{array}{l}1.968(0.689 \\
5.617)\end{array}$ & $\begin{array}{l}1.035(0.380 \\
2.820)\end{array}$ & $\begin{array}{l}1.254(0.466 \\
3.371)\end{array}$ & $\begin{array}{l}1.980(0.734 \\
5.339)\end{array}$ & $\begin{array}{l}2.602(0.946 \\
7.159)\end{array}$ \\
\hline & Q3 & $\begin{array}{l}1.400 \\
4.215)\end{array}$ & $\begin{array}{l}1.780(0.600 \\
5.285)\end{array}$ & $\begin{array}{l}2.698(0.902 \\
8.066)\end{array}$ & $\begin{array}{l}2.016(0.778 \\
5.228)\end{array}$ & $\begin{array}{l}1.425(0.530 \\
3.829)\end{array}$ & $\begin{array}{l}2.081(0.809 \\
5.348)\end{array}$ & $\begin{array}{l}2.088(0.763 \\
5.715)\end{array}$ \\
\hline & Q4 & $\begin{array}{l}1.293(0.477 \\
3.504)\end{array}$ & $\begin{array}{l}1.936 \\
5.359)\end{array}$ & $\begin{array}{l}2.113(0.734 \\
6.080)\end{array}$ & $\begin{array}{l}1.386(0.530 \\
3.622)\end{array}$ & $\begin{array}{l}1.439(0.525 \\
3.939)\end{array}$ & $\begin{array}{l}1.628(0.605 \\
4.381)\end{array}$ & $\begin{array}{l}1.522(0.524 \\
4.423)\end{array}$ \\
\hline & $P$ for trend & 0.561 & 0.286 & 0.221 & 0.344 & 0.47 & 0.357 & 0.735 \\
\hline \multirow{2}{*}{\multicolumn{9}{|c|}{$\begin{array}{l}\mathrm{CO} \\
\left(\mathrm{mg} / \mathrm{m}^{3}\right)\end{array}$}} \\
\hline & & & & & & & & \\
\hline & Q1 & $\begin{array}{l}1.00 \\
\text { 『reference区 }\end{array}$ & $\begin{array}{l}1.00 \\
\text { 『reference区 }\end{array}$ & $\begin{array}{l}1.00 \\
\text { 『reference区 }\end{array}$ & $\begin{array}{l}1.00 \\
\text { 『reference区 }\end{array}$ & $\begin{array}{l}1.00 \\
\text { 『reference区 }\end{array}$ & $\begin{array}{l}1.00 \\
\text { 『reference区 }\end{array}$ & $\begin{array}{l}1.00 \\
\text { 『reference区 }\end{array}$ \\
\hline & Q2 & $\begin{array}{l}1.160(0.436 \\
3.090)\end{array}$ & $\begin{array}{l}1.734(0.599 \\
5.019)\end{array}$ & $\begin{array}{l}1.919(0.674 \\
5.459)\end{array}$ & $\begin{array}{l}1.229(0.433 \\
3.484)\end{array}$ & $\begin{array}{l}1.302(0.494 \\
3.429)\end{array}$ & $\begin{array}{l}0.981(0.374 \\
2.573)\end{array}$ & $\begin{array}{l}1.463(0.532 \\
4.022)\end{array}$ \\
\hline & Q3 & $\begin{array}{l}1.197(0.427 \\
3.353)\end{array}$ & $\begin{array}{l}1.458(0.506 \\
4.206)\end{array}$ & $\begin{array}{l}1.219(0.427 \\
3.478)\end{array}$ & $\begin{array}{l}1.757(0.627 \\
4.924)\end{array}$ & $\begin{array}{l}0.638(0.226 \\
1.804)\end{array}$ & $\begin{array}{l}0.925(0.348 \\
2.455)\end{array}$ & $\begin{array}{l}2.208(0.774 \\
6.297)\end{array}$ \\
\hline & Q4 & $\begin{array}{l}1.291(0.475 \\
3.506)\end{array}$ & $\begin{array}{l}1.646(0.568 \\
4.769)\end{array}$ & $\begin{array}{l}1.881(0.651 \\
5.439)\end{array}$ & $\begin{array}{l}0.649(0.218 \\
1.935)\end{array}$ & $\begin{array}{l}0.914(0.320 \\
2.610)\end{array}$ & $\begin{array}{l}0.860(0.317 \\
2.331)\end{array}$ & $\begin{array}{l}1.429(0.479 \\
4.267)\end{array}$ \\
\hline & $P$ for trend & 0.63 & 0.543 & 0.477 & 0.494 & 0.42 & 0.741 & 0.439 \\
\hline \multicolumn{9}{|l|}{$\begin{array}{l}\mathrm{NO}_{2} \\
\left(\mu \mathrm{g} / \mathrm{m}^{3}\right)\end{array}$} \\
\hline & & & & & & & & \\
\hline & Q1 & $\begin{array}{l}1.00 \\
\text { \reference } \rrbracket\end{array}$ & $\begin{array}{l}1.00 \\
\text { \reference } \rrbracket\end{array}$ & $\begin{array}{l}1.00 \\
\text { \reference } \rrbracket\end{array}$ & 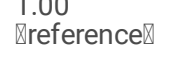 & $\begin{array}{l}1.00 \\
\text { \reference区 }\end{array}$ & $\begin{array}{l}1.00 \\
\text { 『reference】 }\end{array}$ & $\begin{array}{l}1.00 \\
\text { \reference } \rrbracket\end{array}$ \\
\hline & Q2 & $0.661(0.253$ & $0.571(0.233$ & $0.825(0.324$ & $0.340(0.133$ & $0.648(0.270$ & $1.055(0.395$ & $0.884(0.371$ \\
\hline \multicolumn{9}{|c|}{ Page $12 / 14$} \\
\hline
\end{tabular}




\begin{tabular}{|c|c|c|c|c|c|c|c|}
\hline & 1.478) & $1.402)$ & 2.098) & $0.871)$ & $1.557)$ & 2.813) & $2.107)$ \\
\hline Q3 & $\begin{array}{l}0.380(0.152 \\
0.950)\end{array}$ & $\begin{array}{l}0.473(0.187 \\
1.197)\end{array}$ & $\begin{array}{l}0.381(0.153 \\
0.949)\end{array}$ & $\begin{array}{l}1.003(0.426 \\
2.363)\end{array}$ & $\begin{array}{l}0.817(0.350 \\
1.907)\end{array}$ & $\begin{array}{l}0.409(0.174 \\
0.962)\end{array}$ & $\begin{array}{l}0.725(0.293 \\
1.793)\end{array}$ \\
\hline Q4 & $\begin{array}{l}0.507(0.196 \\
1.307)\end{array}$ & $\begin{array}{l}0.436(0.171 \\
1.113)\end{array}$ & $\begin{array}{l}0.527(0.210 \\
1.322)\end{array}$ & $\begin{array}{l}0.428(0.163 \\
1.122)\end{array}$ & $\begin{array}{l}0.643(0.240 \\
1.720)\end{array}$ & $\begin{array}{l}0.612(0.237 \\
1.580)\end{array}$ & $\begin{array}{l}0.758(0.295 \\
1.947)\end{array}$ \\
\hline$P$ for trend & 0.069 & 0.065 & 0.064 & 0.351 & 0.454 & 0.086 & 0.463 \\
\hline \\
\hline \multicolumn{8}{|l|}{$\left(\mu \mathrm{g} / \mathrm{m}^{3}\right)$} \\
\hline Q1 & 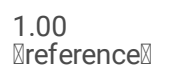 & $\begin{array}{l}1.00 \\
\text { 『reference } \mathbb{}\end{array}$ & $\begin{array}{l}1.00 \\
\text { 『reference区 }\end{array}$ & $\begin{array}{l}1.00 \\
\text { 『reference区 }\end{array}$ & $\begin{array}{l}1.00 \\
\text { 『reference区 }\end{array}$ & $\begin{array}{l}1.00 \\
\text { 『reference区 }\end{array}$ & $\begin{array}{l}1.00 \\
\text { 『reference区 }\end{array}$ \\
\hline Q2 & $\begin{array}{l}2.230(0.860 \\
5.782)\end{array}$ & $\begin{array}{l}1.739(0.693 \\
4.363)\end{array}$ & $\begin{array}{l}1.507(0.617 \\
3.681)\end{array}$ & $\begin{array}{l}2.422(0.972 \\
6.034)\end{array}$ & $\begin{array}{l}2.045(0.769 \\
5.442)\end{array}$ & $\begin{array}{l}1.306(0.514 \\
3.316)\end{array}$ & $\begin{array}{l}1.657(0.629 \\
4.368)\end{array}$ \\
\hline Q3 & $\begin{array}{l}2.899(1.136 \\
7.396)\end{array}$ & $\begin{array}{l}1.470(0.579 \\
3.735)\end{array}$ & $\begin{array}{l}1.369(0.545 \\
3.439)\end{array}$ & $\begin{array}{l}1.565(0.615 \\
3.983)\end{array}$ & $\begin{array}{l}3.184(1.175 \\
8.627)\end{array}$ & $\begin{array}{l}1.788(0.680 \\
4.703)\end{array}$ & $\begin{array}{l}1.616(0.594 \\
4.395)\end{array}$ \\
\hline Q4 & $\begin{array}{l}0.828(0.298 \\
2.298)\end{array}$ & $\begin{array}{l}1.089(0.430 \\
2.758)\end{array}$ & $\begin{array}{l}0.911(0.368 \\
2.257)\end{array}$ & $\begin{array}{l}0.857(0.329 \\
2.232)\end{array}$ & $\begin{array}{l}1.041(0.365 \\
2.974)\end{array}$ & $\begin{array}{l}0.946 \\
2.565)\end{array}(0.349$ & $\begin{array}{l}0.863(0.296 \\
2.520)\end{array}$ \\
\hline$P$ for trend & 0.999 & 0.941 & 0.831 & 0.543 & 0.732 & 0.949 & 0.679 \\
\hline \multicolumn{8}{|l|}{ AQI } \\
\hline Q1 & $\begin{array}{l}1.00 \\
\text { 『reference } \bigotimes\end{array}$ & $\begin{array}{l}1.00 \\
\text { 『reference } \bigotimes\end{array}$ & $\begin{array}{l}1.00 \\
\text { \reference区 }\end{array}$ & $\begin{array}{l}1.00 \\
\text { 『reference区 }\end{array}$ & $\begin{array}{l}1.00 \\
\text { 『reference区 }\end{array}$ & $\begin{array}{l}1.00 \\
\text { 『reference } \bigotimes\end{array}$ & $\begin{array}{l}1.00 \\
\text { 『reference区 }\end{array}$ \\
\hline Q2 & $\begin{array}{l}0.897(0.363 \\
2.215)\end{array}$ & $\begin{array}{l}0.782(0.316 \\
1.934)\end{array}$ & $\begin{array}{l}1.057(0.422 \\
2.645)\end{array}$ & $\begin{array}{l}1.727(0.669 \\
4.456)\end{array}$ & $\begin{array}{l}0.987(0.420 \\
2.321)\end{array}$ & $\begin{array}{l}0.937(0.397 \\
2.213)\end{array}$ & $\begin{array}{l}1.334(0.558 \\
3.189)\end{array}$ \\
\hline Q3 & $\begin{array}{l}0.293(0.112 \\
0.768)\end{array}$ & $\begin{array}{l}0.630(0.258 \\
1.535)\end{array}$ & $\begin{array}{l}0.708(0.278 \\
1.800)\end{array}$ & $\begin{array}{l}0.671(0.258 \\
1.741)\end{array}$ & $\begin{array}{l}0.991(0.391 \\
2.513)\end{array}$ & $\begin{array}{l}0.680(0.268 \\
1.721)\end{array}$ & $\begin{array}{l}0.464(0.181 \\
1.185)\end{array}$ \\
\hline Q4 & $\begin{array}{l}0.689(0.275 \\
1.726)\end{array}$ & $\begin{array}{l}0.479(0.189 \\
1.210)\end{array}$ & $\begin{array}{l}0.576(0.228 \\
1.456)\end{array}$ & $\begin{array}{l}0.306(0.115 \\
0.814)\end{array}$ & $\begin{array}{l}0.532 \\
1.395)\end{array}$ & $\begin{array}{l}0.471(0.178 \\
1.250)\end{array}$ & $\begin{array}{l}0.521 \\
1.358)\end{array}(0.200$ \\
\hline $\mathrm{P}$ for trend & 0.127 & 0.106 & 0.176 & 0.005 & 0.236 & 0.11 & 0.051 \\
\hline
\end{tabular}

$A O R$, adjusted odds ratio; $\mathrm{Cl}$, confidence interval; $\mathrm{P} 1$, period 1; $\mathrm{P} 2$, period 2; $\mathrm{P} 3$, period 3; $\mathrm{P} 4$, period 4; P5, period 5; P6, period 6; P7, period 7; PM 10 , particulate matter $\leq 10 \mu \mathrm{m}$ in aerodynamic diameter; $\mathrm{PM}_{2.5}$, particulate matter $\leq 2.5 \mu \mathrm{m}$ in aerodynamic diameter; $\mathrm{SO}_{2}$, sulfur dioxide; $\mathrm{CO}$, carbon monoxide; $\mathrm{NO}_{2}$, nitrogen dioxide; $\mathrm{O}_{3}$, ozone; $\mathrm{AQI}$, air quality index; $\mathrm{Q} 1$, the first quartile; Q2, the second quartile; $\mathrm{Q} 3$, the third quartile; $\mathrm{Q} 4$, the fourth quartile.

Adjusting for age, BMI, duration of infertility, type of infertility, causes of infertility, IVF/ICSI, basal FSH, basal LH, basal E2 and number of oocytes retrieved.

\section{Figures}

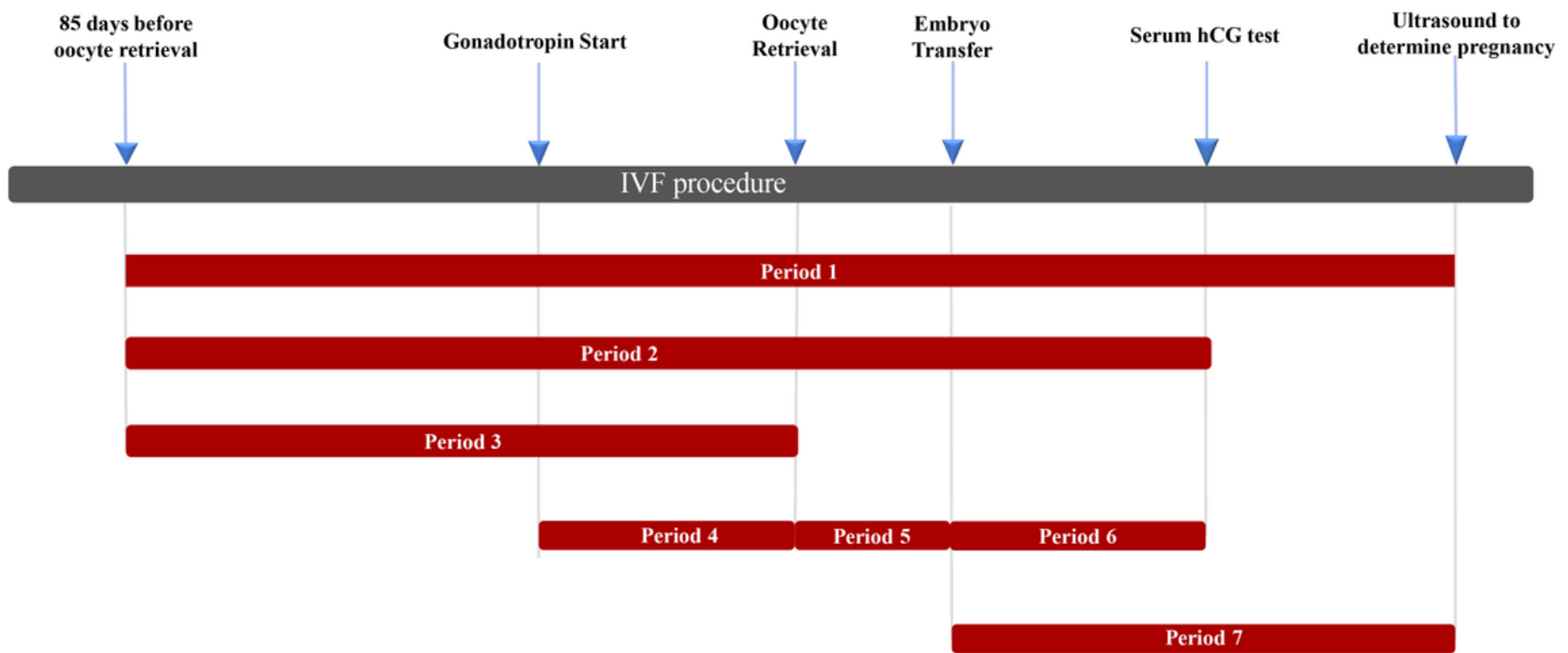


Figure 1

Timeline of an IVF cycle and the observed exposure time point for current study.

\section{Supplementary Files}

This is a list of supplementary files associated with this preprint. Click to download.

- Additionalfile2.docx

- Additionalfile1.docx 